\title{
Barriers and Facilitators Associated with Physical Activity in the Middle East and North Africa Region: A Systematic Overview
}

\author{
Sonia Chaabane, Karima Chaabna, Sathyanarayanan Doraiswamy ${ }^{\mathbb{D}}$, Ravinder Mamtani and Sohaila Cheema * \\ Institute for Population Health, Weill Cornell Medicine-Qatar, Education City, Doha 24144, Qatar; \\ sonia.chaabane.phd@gmail.com (S.C.); kac2047@qatar-med.cornell.edu (K.C.); \\ sdo4003@qatar-med.cornell.edu (S.D.); ram2026@qatar-med.cornell.edu (R.M.) \\ * Correspondence: soc2005@qatar-med.cornell.edu; Tel.: +974-44928503; Fax: +974-44928333
}

check for updates

Citation: Chaabane, S.; Chaabna, K.; Doraiswamy, S.; Mamtani, R.; Cheema, S. Barriers and Facilitators Associated with Physical Activity in the Middle East and North Africa Region: A Systematic Overview. Int. J. Environ. Res. Public Health 2021, 18, 1647. https://doi.org/10.3390/ijerph 18041647

Academic Editors: David Berrigan and Marieke De Craemer Received: 29 November 2020

Accepted: 5 February 2021

Published: 9 February 2021

Publisher's Note: MDPI stays neutral with regard to jurisdictional claims in published maps and institutional affiliations.

Copyright: (c) 2021 by the authors. Licensee MDPI, Basel, Switzerland. This article is an open access article distributed under the terms and conditions of the Creative Commons Attribution (CC BY) license (https:/ / creativecommons.org/licenses/by/ $4.0 /)$.
Abstract: Increasing physical inactivity levels in the Middle East and North Africa (MENA) region is a public health concern. We aimed to synthesize barriers and facilitators to physical activity and make appropriate recommendations to address physical inactivity. We conducted an overview of systematic reviews on physical activity barriers and facilitators in 20 MENA countries by systematically searching MEDLINE/PubMed and Google Scholar for systematic reviews published between 2008 and 2020. Our overview included four systematic reviews and 119 primary studies with data from 17 MENA countries. Lack of suitable sports facilities, time, social support and motivation, gender and cultural norms, harsh weather, and hot climate were the most commonly reported barriers to physical activity. Socio-demographic factors negatively associated with physical activity participation include advanced age, being female, less educated, and being married. Motivation to gain health benefits, losing/maintaining weight, being male, dietary habits, recreation, and increased Body Mass Index are positively associated with increased levels of physical activity. Interventions promoting physical activity in MENA should target schoolchildren, women and girls, working parents, and the elderly. Country-specific sociocultural and environmental factors influencing physical activity should be considered in the design of interventions. Current and future policies and national interventions must be consistently evaluated for effectiveness and desired outcomes.

Keywords: physical activity; barriers; inactivity; systematic review; Middle East; North Africa

\section{Introduction}

For optimal health benefit, it is recommended for adults to accumulate at least $150 \mathrm{~min}$ of moderate-intensity physical activity (PA) per week [1]; whereas, at least 60 min per day of moderate-to-vigorous-intensity PA helps children and youth maintain a healthy cardiorespiratory and metabolic risk profile [2]. Within the Middle East and North Africa (MENA) region, it is estimated that about $49 \%$ of adults and $75 \%$ of the youth population are not sufficiently active to meet the recommended international guidelines for PA [3].

Countries in the MENA region have some of the highest rates of diabetes and obesity in the world [4-6]. In recent decades, urbanization and advances in technology and transportation have led to increased sedentary lifestyles in the region [7]. Changes in the working environment (working from home, widespread use of telecommunication, etc.) have increased the time that individuals spend sitting [8]. The reduction in daily energy spent at work led to an increased body weight [8]. Moreover, low PA participation is of concern because it may have a detrimental effect on mental health and quality of life for children, youth, and adults [2,9]. The current living environment in several MENA countries is characterized by an increased availability of unhealthy food combined with a lifestyle requiring low levels of PA [7], promoting high energy intake, and low energy expenditure [7,10-13], all of which are major risk factors for non-communicable diseases (NCDs). Reducing NCD risk has become an important goal for the whole region due to 
the changing demographics in low- and middle-income countries in the region and high health care and treatment costs associated with these diseases [14].

Although some MENA countries are increasing the number of parks available and improving access to sports facilities for their residents $[15,16]$, others are lagging behind. In order for MENA countries to be successful in implementing interventions that facilitate $\mathrm{PA}$, it is important to understand the barriers and facilitators of PA programs within their specific populations. We need to identify country-specific factors associated with low PA participation in order to better customize interventions to local needs [7]. Our study objective is to identify and explore factors positively associated (facilitators) and negatively associated (barriers) with PA. This review will help inform academics, researchers, and policymakers, thus enabling them to make informed decisions about how to improve PA participation in the MENA region.

\section{Materials and Methods}

We conducted a systematic overview of published systematic reviews (SRs) on the epidemiology of PA in the MENA region. In a previous publication, we synthesized data on the prevalence of PA and sedentary behavior [3]. In this present study, we focus on synthesizing country-specific barriers and facilitators associated with PA in the MENA region.

\subsection{Search Strategy and Selection Criteria}

A broad search strategy was developed to systematically identify any type of review on all health issues in any MENA country $[3,17]$. We used search terms related to the names of MENA countries, regions and sub-regions. The detailed search strategy is available as Supplementary Materials (Panel 1). No restrictions to a specific health condition or language of publication were applied at this stage [18]. The detailed search strategy is available in our previous publications $[3,17]$. Two independent reviewers systematically searched the Medical Literature Analysis and Retrieval System Online (MEDLINE) through the search engine PubMed. We included publications since 2008- the publication year of the first version of the Cochrane Handbook for Systematic Reviews of Interventions [19] up to November 2019. We also searched Google Scholar for primary studies (grey and non-grey literature), with no date nor language restriction, up to April 2020. Additionally, a manual search of the references from the included studies was also conducted.

\subsection{Inclusion and Exclusion Criteria}

While we searched for any type of literature review, we included only SRs. An SR was defined as a literature review that explicitly used a systematic literature search of at least one electronic database to identify all studies that met pre-defined eligibility criteria, and that reported the process of study selection [19]. We considered any kind of PA that people do as part of their everyday lives (leisure time PA and/or physical labor).

MENA countries, where the primary official languages and/or the medium of instruction in the colleges/universities was Arabic, English, French, and/or Urdu, were included. The authors of this overview are fluent and proficient in these languages [17]. The 20 MENA countries included in the study are Algeria, Bahrain, Djibouti, Egypt, Iraq, Jordan, Kuwait, Lebanon, Libya, Morocco, Oman, Pakistan, Palestine, Qatar, Saudi Arabia, Sudan, Syria, Tunisia, the United Arab Emirates (UAE), and Yemen.

\subsection{Data Screening}

The retrieved reviews were downloaded into Endnote (version X8.2) and duplicates were removed. Using Rayyan software [20], two independent reviewers conducted the multi-stage screening. Discrepancies in the inclusion of SRs were resolved through discussion with a third reviewer. 


\subsection{Data Extraction}

One reviewer extracted the data, and another reviewer checked the accuracy of the extracted data. From each included SR, the following characteristics were extracted: reported factors associated with PA, study period, geographical coverage of the literature search, the corresponding MENA countries for which data was available, and literature sources, as well as the number of included studies and the study target population. The characteristics of the primary studies included in our overview, along with the methodological quality assessment and study selection process, are described in a previous publication [3] Where available, we extracted factors associated with PA specific to different age groups (youth and adults) and gender (boys/girls or males/females).

We classified the MENA countries into high and low-middle income countries using the World Bank classification by income [21]. High-income MENA countries include Bahrain, Kuwait, Oman, Qatar, Saudi Arabia, and UAE [21]. Low- and middle-income MENA countries include: Algeria, Djibouti, Egypt, Iraq, Jordan, Lebanon, Libya, Morocco, Pakistan, Palestine, Sudan, Syria, Tunisia, and Yemen [21]. We used the number of studies reporting each barrier, facilitator, or correlate of PA in each country to identify the most frequently reported barrier, facilitator, and correlate of PA in those countries.

\subsection{Methodological Quality Assessment}

The original AMSTAR critical appraisal tool for SRs [22] was used by two independent reviewers to perform and discuss the quality assessment of the included SRs.

\subsection{Data Synthesis}

For the purpose of data synthesis and discussion, reported factors associated with PA were first grouped into six categories: (1) sociodemographic, (2) intrapersonal, (3) interpersonal, (4) physical environment, (5) sociocultural, and (6) organizational and policy [23]. We further sub-grouped these factors as barriers (factors negatively associated with PA) and facilitators (factors positively associated with PA) among the whole population of any age group residing in a MENA country.

\section{Results}

Our search strategy identified four SRs that included 142 primary studies reporting on factors (barriers or facilitators) associated with PA in at least one of the 20 MENA countries (Figure 1). After excluding primary studies included in more than one SR $(n=23)$, we considered a total of 119 studies for the qualitative synthesis.

\subsection{Characteristics and Methodological Quality of the Included Systematic Reviews}

The four SRs included in our overview are described in Table 1. Data on barriers and facilitators of PA were identified for seventeen MENA countries, namely Bahrain, Egypt, Jordan, Iraq, Kuwait, Libya, Lebanon, Morocco, Oman, Pakistan, Palestine, Qatar, Saudi Arabia, Syria, Sudan, Tunisia, and the United Arab Emirates (UAE). Data on children and adolescents (youth), as well as adults, were identified. No SR reported the list of excluded studies, assessed publication bias, included the funding source of both the SR and of the included primary studies, nor searched for grey literature sources as per the AMSTAR recommendations [24]. 


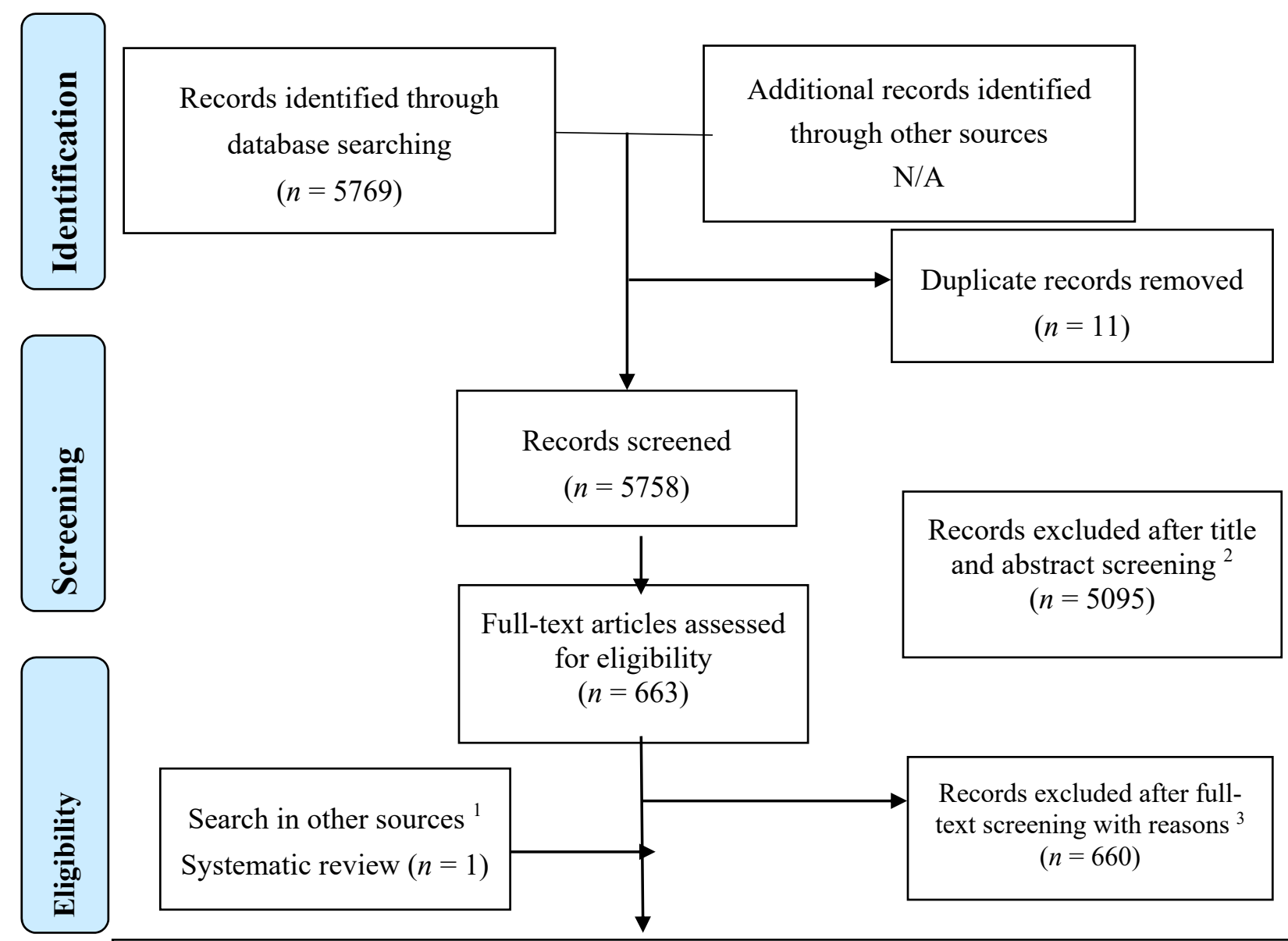

Systematic reviews included in qualitative synthesis on PA related outcomes $(n=4)$

Primary studies included in qualitative synthesis on PA, physical inactivity, and sedentary behavior $(n=142)$

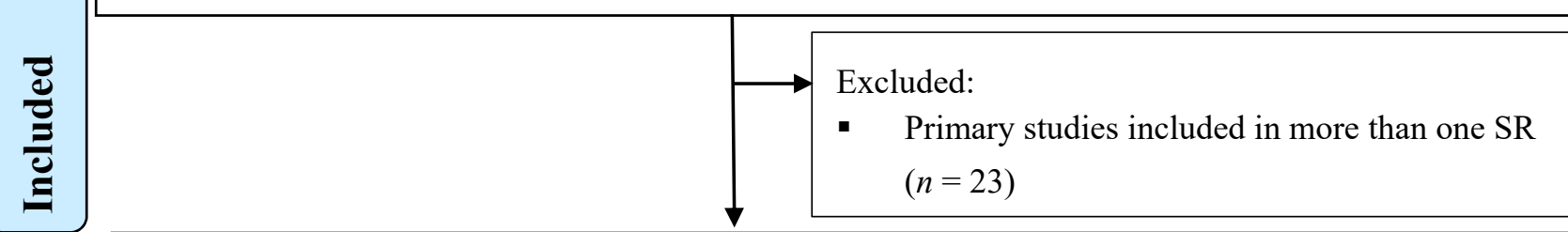

Primary studies on factors association with the participation in physical activity included in the synthesis

$$
(n=119)
$$

Figure 1. Preferred Reporting Items for Systematic Reviews and Meta-Analyses (PRISMA) 2009 flowchart of the systematic reviews inclusion. ${ }^{1}$ Google Scholar and manual search of the references in the included studies. ${ }^{2}$ Systematic reviews were excluded from the overview because they did not meet our inclusion criteria; ${ }^{3}$ not a systematic review $(n=116)$, no data on barriers to physical activity $(n=507)$, not a population from MENA $(n=34)$, duplicate $(n=1)$, and publication in Portuguese $(n=1)$, a systematic review with qualitative data only $(n=1)$. 
Table 1. List of included systematic reviews with data on factors (barriers and facilitators) associated with physical activity in Middle East and North Africa (MENA) countries.

\begin{tabular}{|c|c|c|c|c|c|c|}
\hline $\begin{array}{l}\text { Systematics } \\
\text { Review }\end{array}$ & $\begin{array}{l}\text { Literature } \\
\text { Search } \\
\text { Period }\end{array}$ & $\begin{array}{l}\text { Literature } \\
\text { Search } \\
\text { Geographical } \\
\text { Coverage }\end{array}$ & Data Sources & $\begin{array}{l}\text { MENA Countries } \\
\text { with Identified } \\
\text { Data }\end{array}$ & $\begin{array}{l}\text { Number } \\
\text { of } \\
\text { Included } \\
\text { Studies } \\
\text { on } \\
\text { MENA }\end{array}$ & $\begin{array}{c}\text { Targeted } \\
\text { Review } \\
\text { Population }\end{array}$ \\
\hline $\begin{array}{c}\text { Mabry, } 2016 \\
\text { [25] }\end{array}$ & Up to 2016 & $\begin{array}{l}\text { Oil-producing } \\
\text { countries of the } \\
\text { Arabian } \\
\text { Peninsula }\end{array}$ & $\begin{array}{c}\text { PubMed } \\
\text { Web of Science } \\
\text { Knowledge } \\
\text { Google Scholar } \\
\text { Web Search Engine }\end{array}$ & $\begin{array}{c}\text { Saudi Arabia, UAE, } \\
\text { Oman, Qatar, } \\
\text { Kuwait, Bahrain }\end{array}$ & 35 & $\begin{array}{l}\text { Youth and adult } \\
\text { general } \\
\text { population }\end{array}$ \\
\hline $\begin{array}{c}\text { Al-Hazzaa, } \\
2018 \text { [26] }\end{array}$ & $\begin{array}{l}\text { Up to } 15 \\
\text { January } \\
2018\end{array}$ & Saudi Arabia & $\begin{array}{l}\text { MEDLINE and Google } \\
\text { Scholar }\end{array}$ & Saudi Arabia & 21 & $\begin{array}{l}\text { Youth and adult } \\
\text { population }\end{array}$ \\
\hline $\begin{array}{l}\text { Sharara, } \\
2018 \text { [27] }\end{array}$ & 2000 to 2016 & $\begin{array}{l}22 \text { Arab } \\
\text { countries }\end{array}$ & $\begin{array}{l}\text { MEDLINE, Popline and } \\
\text { Social Sciences, Citation } \\
\text { Index, reference lists of } \\
\text { the articles, WHO } \\
\text { surveys on } \\
\text { non-communicable } \\
\text { disease risk factors } \\
\text { (STEPS), Global } \\
\text { School-based Student } \\
\text { Health Surveys (GSHS) }\end{array}$ & $\begin{array}{l}\text { Algeria, Bahrain, } \\
\text { Djibouti, Egypt, } \\
\text { Iraq, Jordan, } \\
\text { Kingdom of Saudi } \\
\text { Arabia (KSA), } \\
\text { Kuwait, Lebanon, } \\
\text { Libya, Morocco, } \\
\text { Oman, Palestine, } \\
\text { Qatar, Sudan, Syria, } \\
\text { Tunisia, UAE, } \\
\text { and Yemen }\end{array}$ & 79 & $\begin{array}{l}\text { Adult and chil- } \\
\text { dren/adolescent }\end{array}$ \\
\hline $\begin{array}{l}\text { Benjamin } \\
2013[28]\end{array}$ & 2002-2013 & $\begin{array}{l}\text { Middle Eastern } \\
\text { countries }\end{array}$ & $\begin{array}{l}\text { MEDLINE, Cumulative } \\
\text { Index to Nursing and } \\
\text { Allied Health Literature } \\
\text { (CINAHL), } \\
\text { SPORTdiscus, and } \\
\text { Middle Eastern and } \\
\text { Central Asian Studies }\end{array}$ & $\begin{array}{l}\text { Saudi Arabia, UAE, } \\
\text { Kuwait, Qatar }\end{array}$ & 7 & Adult \\
\hline
\end{tabular}

\subsection{Synthesis of Data on PA Barriers and Facilitators}

Table 2 describes extracted barriers and facilitators associated with PA in MENA countries. Two studies reported data on the sub-region of Arab countries, namely Algeria, Djibouti, Egypt, Jordan, Kuwait, Libya, Morocco, Oman, Palestine, Syria, and the UAE. Most studies reporting PA barriers and facilitators were conducted in high-income MENA countries, mainly Saudi Arabia and the UAE. Except for the SR of Benjamin, 2013 [28], all SRs included data on adults and youth. Only the SR of Al-Hazzaa, 2018 [26], segregated PA barriers and facilitators by gender and age groups (children, adolescents, and adults) among the Saudi population. 
Table 2. Factors (barriers and facilitators) associated with physical activity in MENA.

\begin{tabular}{|c|c|c|c|}
\hline & Country & Direction of the Association & Factors Associated with Participation in PA \\
\hline 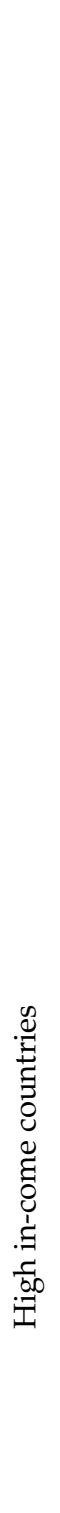 & $\begin{array}{c}\text { Saudi } \\
\text { Ara- } \\
\text { bia }\end{array}$ & - & 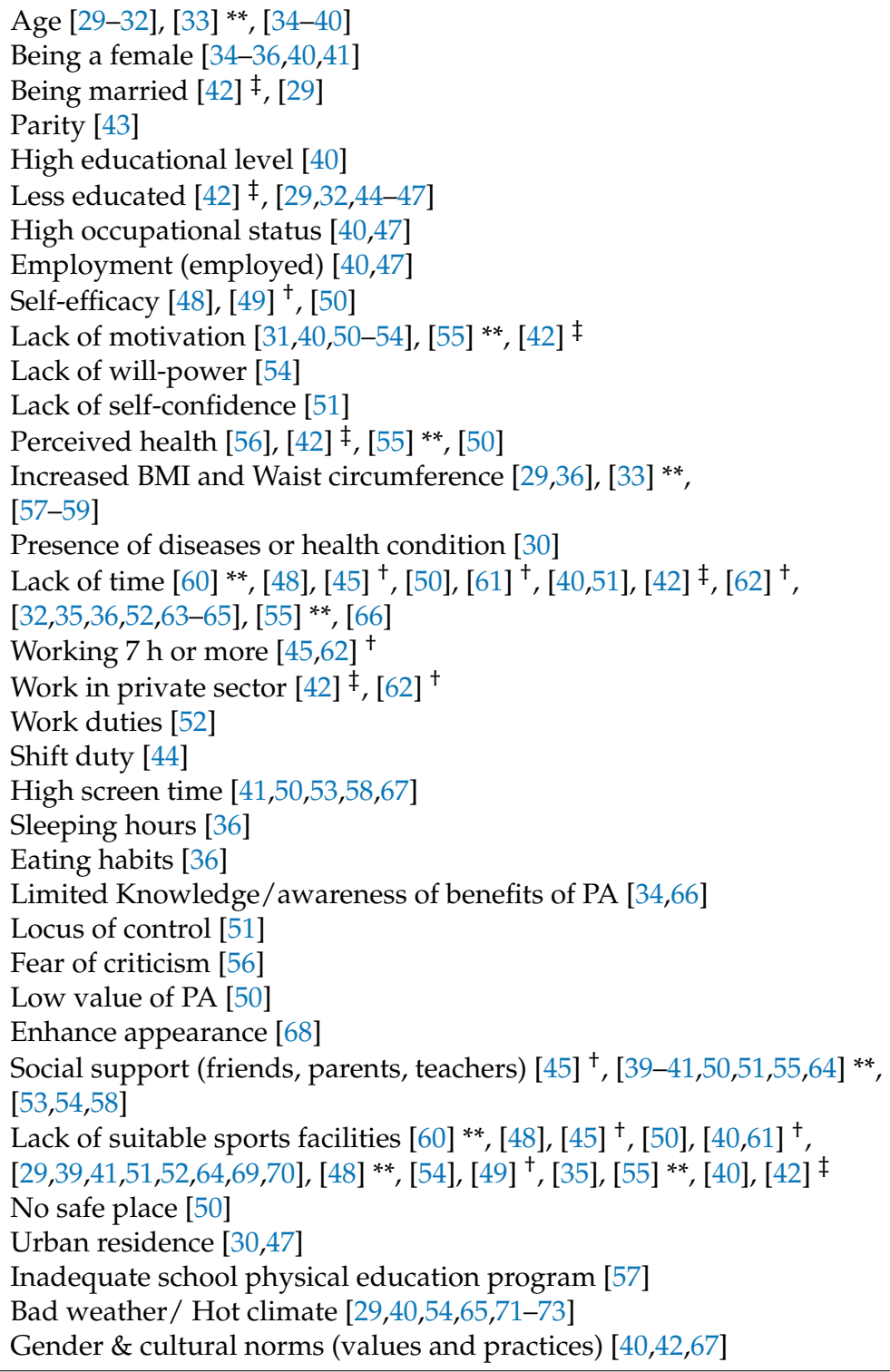 \\
\hline & & + & 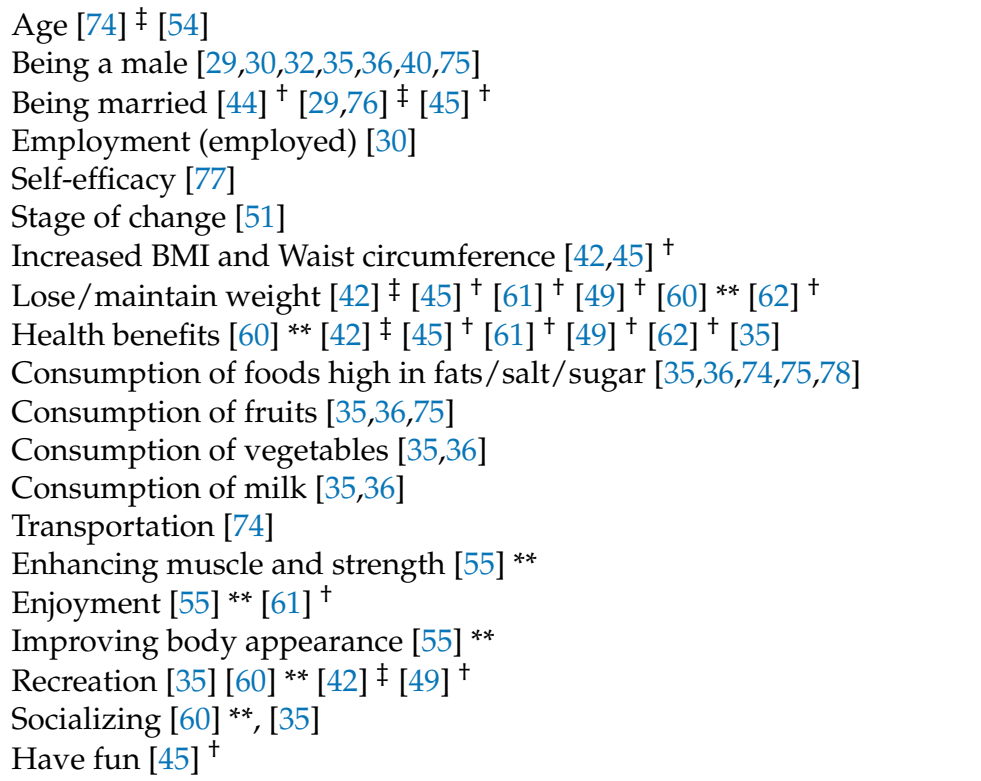 \\
\hline
\end{tabular}


Table 2. Cont.

\begin{tabular}{|c|c|c|}
\hline Country & Direction of the Association & Factors Associated with Participation in PA \\
\hline \multirow[t]{2}{*}{ Kuwait } & - & $\begin{array}{l}\text { Age [79] } \\
\text { Being married [80] } \\
\text { Less educated [81] } \\
\text { Perceived Health [82] } \\
\text { Increased BMI and Waist circumference [80] } \\
\text { Presence of diseases or health condition [82] } \\
\text { Lack of time [7,82] } \\
\text { Excessive use of private cars [82] } \\
\text { Lack of exercise partner [82] } \\
\text { Bad weather/ Hot climate [73,82,83] } \\
\text { Gender \& cultural norms (values and practices) [84] } \\
\text { Having more domestic workers than one needs [82] }\end{array}$ \\
\hline & + & Being married [84] \\
\hline \multirow[t]{2}{*}{ UAE } & - & $\begin{array}{l}\text { Age [38,85,86] } \\
\text { Being married [87] } \\
\text { Less educated [86,87] } \\
\text { Lack of motivation [63,88] } \\
\text { Lack of will-power [88] } \\
\text { Fear of injury [88] } \\
\text { Exercise is boring [88] } \\
\text { Embarrassed to wear exercise clothes [88] } \\
\text { Belief that exercise makes control of diabetes difficult [88] } \\
\text { Presence of diseases or health condition [88] } \\
\text { Lack of time [88-91] } \\
\text { Family responsibilities [88] } \\
\text { High screen time [89] } \\
\text { Limited Knowledge/ awareness of benefits of PA [92] } \\
\text { Belief in overweight as normal [90] } \\
\text { Attitude to changing diet [90] } \\
\text { Low value of PA [90] } \\
\text { Social support (friends, parents, teachers) [88] } \\
\text { Lack of suitable sports facilities [63,88-90,93] } \\
\text { No safe place [88,90] } \\
\text { Cost of joining gym [88] } \\
\text { Bad weather/ Hot climate [63,73,88-90,93,94] } \\
\text { Limited material resources in health centers (teaching materials, guidelines) } \\
\text { [90] } \\
\text { Limited availability of human resources (i.e., dietitians) [90] } \\
\text { Gender \& cultural norms (values and practices) [38,63,89,93-95] } \\
\text { Difficulty of joining gym for women-few centers for women only [88] } \\
\text { Norms promoting overeating [90] } \\
\text { Ineffective health communication [90] } \\
\text { Ineffective PA supportive policies in colleges [63] }\end{array}$ \\
\hline & + & $\begin{array}{l}\text { Employment (employed) [87] } \\
\text { Presence of diseases or health condition [89] } \\
\text { Social support (friends, parents, teachers) [89] } \\
\text { Living on a farm [89] } \\
\text { Cooler weather [89] }\end{array}$ \\
\hline
\end{tabular}


Table 2. Cont.

\begin{tabular}{|c|c|c|}
\hline Country & Direction of the Association & Factors Associated with Participation in PA \\
\hline \multirow[t]{2}{*}{ Qatar } & - & $\begin{array}{l}\text { Maintain health [68] } \\
\text { Presence of diseases or health condition [96] } \\
\text { Lack of time [68,97] } \\
\text { Family responsibilities [96] } \\
\text { Priority on caring for family-not exercise [96] } \\
\text { High screen time [58,98] } \\
\text { Limited Knowledge/ awareness of benefits of PA [68] } \\
\text { Social support (friends, parents, teachers) [99] } \\
\text { Lack of suitable sports facilities [58,99] } \\
\text { Bad weather/ Hot climate [73,96] } \\
\text { Gender \& cultural norms (values and practices) }[63,96] \\
\text { Taboo for females to go out in public places unless accompanied by male } \\
\text { family member [96] } \\
\text { Having more servants than one needs [96] }\end{array}$ \\
\hline & + & $\begin{array}{l}\text { Increased BMI and Waist circumference [97] } \\
\text { Knowledge PA is important }[99,100] \\
\text { Feeling healthy and looking younger participants expressed desire for slimmer } \\
\text { bodies [99] } \\
\text { Low cost and accessible facilities [99] } \\
\text { Religion- Quran supportive of exercise [99] }\end{array}$ \\
\hline Bahrain & - & $\begin{array}{l}\text { Lack of time [101] } \\
\text { Bad weather/ Hot climate [73] } \\
\text { Limited material resources in health centers (teaching materials, guidelines) } \\
\text { [101] } \\
\text { Lack of specialty clinics at primary health care level [101] } \\
\text { Gender \& cultural norms (values and practices) [13] }\end{array}$ \\
\hline \multirow[t]{2}{*}{ Oman } & - & $\begin{array}{l}\text { Age [76] }^{\dagger} \\
\text { High educational level [76] } \\
\text { Lack of motivation [102,103] } \\
\text { Increased BMI and Waist circumference [76] } \\
\text { Lack of time [102,103] } \\
\text { Consumption of fruits [76] } \\
\text { Low value of PA [102] } \\
\text { Social support (friends, parents, teachers) [102] } \\
\text { Lack of suitable sports facilities [102] } \\
\text { Bad weather/ Hot climate [73,102] } \\
\text { Gender \& cultural norms (values and practices) [102] } \\
\text { Ineffective health communication [102] }\end{array}$ \\
\hline & + & $\begin{array}{l}\text { Age [76] }{ }^{\ddagger} \\
\text { Employment (employed) [76] } \\
\text { Consumption of vegetables [76] }\end{array}$ \\
\hline Libya & - & Lack of suitable sports facilities [104] \\
\hline Tunisia & - & $\begin{array}{l}\text { Age [85] } \\
\text { Lack of time [105] } \\
\text { Smoking }[105,106] \\
\text { Urban residence [107] } \\
\text { Gender \& cultural norms, traditional cultural values and practices }[105,108]\end{array}$ \\
\hline Pakistan & - & Age [85] \\
\hline
\end{tabular}


Table 2. Cont.

\begin{tabular}{|c|c|c|c|}
\hline & Country & Direction of the Association & Factors Associated with Participation in PA \\
\hline \multirow{10}{*}{ 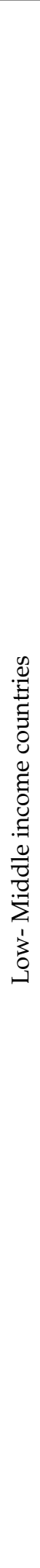 } & \multirow[t]{2}{*}{ Lebanon } & - & $\begin{array}{l}\text { Age [109,110] } \\
\text { Being married [110,111] } \\
\text { High educational level [109] } \\
\text { Less educated [112] } \\
\text { Socioeconomic status [109] } \\
\text { Increased BMI and Waist circumference }[109,110,113] \\
\text { Presence of diseases or health condition }[109,110] \\
\text { Lack of time [112] } \\
\text { Alcohol [112] } \\
\text { Smoking [110,112] } \\
\text { Social support (friends, parents, teachers) [112] } \\
\text { Lack of suitable sports facilities [114-116] } \\
\text { Urban residence [109] } \\
\text { Gender \& cultural norms, traditional cultural values and practices [114] }\end{array}$ \\
\hline & & + & $\begin{array}{l}\text { Employment (employed) [112,117] } \\
\text { Socioeconomic status [111] } \\
\text { Increased BMI and Waist circumference [112] } \\
\text { Smoking [118] }\end{array}$ \\
\hline & Morocco & - & $\begin{array}{l}\text { Age [119] } \\
\text { Being married [120] } \\
\text { Socioeconomic status [120,121] } \\
\text { Increased BMI and Waist circumference [119] } \\
\text { Lack of suitable sports facilities [122,123] } \\
\text { Gender \& cultural norms, traditional cultural values and practices [121-124] }\end{array}$ \\
\hline & Egypt & - & $\begin{array}{l}\text { Less educated [125] } \\
\text { Socioeconomic status [125] } \\
\text { Lack of motivation }[125,126] \\
\text { Presence of diseases or health condition }[126] \\
\text { Lack of time [125] } \\
\text { High screen time [127] } \\
\text { Social support (friends, parents, teachers) }[125,128] \\
\text { Lack of suitable sports facilities }[125,128] \\
\text { Bad weather/Hot climate [125] } \\
\text { Gender \& cultural norms, traditional cultural values and practices }[125,128]\end{array}$ \\
\hline & Syria & - & $\begin{array}{l}\text { Age }[129,130] \\
\text { Being married [129] } \\
\text { Less educated [130] } \\
\text { Socioeconomic status [130] }\end{array}$ \\
\hline & & + & Employment (employed) [130] \\
\hline & Palestine & - & $\begin{array}{l}\text { Age [131] } \\
\text { Less educated [131] } \\
\text { Urban residence [132] } \\
\text { Gender \& cultural norms, traditional cultural values and practices [132] }\end{array}$ \\
\hline & Iraq & - & $\begin{array}{l}\text { Age [133] } \\
\text { Gender \& cultural norms, traditional cultural values and practices [134] }\end{array}$ \\
\hline & Jordan & - & $\begin{array}{l}\text { Age [135] } \\
\text { Gender \& cultural norms, traditional cultural values and practices [136-139] }\end{array}$ \\
\hline & Sudan & - & $\begin{array}{l}\text { Age [140] } \\
\text { Less educated [140] }\end{array}$ \\
\hline
\end{tabular}


Table 2. Cont.

\begin{tabular}{cccl}
\hline & Country & Direction of the Association & \multicolumn{1}{c}{ Factors Associated with Participation in PA } \\
\hline & & Socioeconomic status [141] \\
Lack of time [7] & Social support (friends, parents, teachers) [7] \\
Arab & Arab & Lack of suitable sports facilities [7,142] \\
tries & tries & Bad weather/Hot climate [7] \\
& & Gender \& cultural norms, traditional cultural values and practices [7] \\
\hline
\end{tabular}

+: Factors positively associated with an increased participation in PA (facilitators). -: Factors negatively associated with an increased participation in PA (barriers). BMI: Body Mass Index. ${ }^{\dagger}$ Females only. ${ }^{\ddagger}$ Males only. ${ }^{* *}$ Boys only.

Considering any population (all ages, both genders), the most commonly reported barriers to PA were: lack of suitable sports facilities (number of studies reporting this factor $[n]=43)$, lack of time $(n=36)$, gender norms (e.g., difficulty for women in joining a gym) and cultural norms (e.g., norms promoting overeating) $(n=32)$, harsh weather and hot climate $(n=24)$, lack of social support $(n=19)$, and lack of motivation $(n=15)$. These barriers were reported in most of the MENA countries and more frequently in the high-income countries. The most commonly reported sociodemographic barriers to PA were age (elderly people being more inactive than younger people $(n=25)$, being less educated $(n=15)$, being married $(n=7)$, and being female $(n=5)$. Considering any population (all ages, both genders), the commonly reported PA facilitators were being male $(n=7)$, motivation to gain health benefits $(n=7)$, losing/maintaining weight $(n=6)$, the consumption of foods high in fats/salt/sugar $(n=5)$, increased Body Mass Index and waist circumference $(n=4)$, recreation $(n=4)$, and consumption of healthy food (fruits, vegetables, milk) $(n=3)$.

PA barriers for boys (children and adolescents) included obesity $(n=2)$, age $(n=1)$, inadequate school physical education program $(n=1)$, lack of sports facilities $(n=1)$, lack of time $(n=1)$, and lack of friends' support $(n=1)$. No data on PA barriers among girls (children and adolescents) was reported in the included SRs. PA barriers among adult males included lack of time $(n=2)$, no suitable place $(n=1)$, being married $(n=1)$, work in private section $(n=1)$, less educated $(n=1)$, and high educational level $(n=1)$. PA barriers for adult females included lack of time $(n=3)$, no suitable place $(n=1)$, no one to exercise with $(n=1)$, no access to sport facilities $(n=2)$, low self-efficacy $(n=1)$, working in private sector $(n=1)$, working seven or more hours $(n=1)$, and age $(n=1)$. PA barriers for youth included high screen time $(n=1)$, being female $(n=4)$, obesity $(n=2)$, older age $(n=4)$, inadequate school physical education program $(n=1)$, knowledge about obesity prevention $(n=1)$, lack of time $(n=3)$, no suitable place $(n=1)$, lack of sports facilities $(n=1)$, lack of friends' support $(n=1)$, waist circumference $(n=1)$, sleeping hours $(n=1)$, and eating habits $(n=1)$.

PA facilitators among boys (children and adolescents) included enhancing muscle and strength $(n=1)$, enjoyment $(n=1)$, and improving body appearance $(n=1)$. No data were available for specific PA facilitators among girls in the included SRs. Male PA facilitators included age $(n=2)$, getting health benefits $(n=2)$, recreation $(n=2)$, socializing $(n=1)$, being married $(n=1)$, and losing weight $(n=1)$. Female PA facilitators included getting health benefits $(n=4)$, lose/maintain weight $(n=4)$, have fun $(n=1)$, enjoyment $(n=1)$, being married $(n=1)$, and recreation $(n=1)$. PA facilitators among children and adolescents included getting health benefits $(n=1)$, lose weight $(n=1)$, recreation $(n=1)$, socializing with others $(n=1)$, enhancing muscle and strength $(n=1)$, enjoyment $(n=1)$, and improving body appearance $(n=1)$.

\section{Discussion}

Our overview included four SRs and 119 primary studies, with data from 17 MENA countries. The lack of suitable sports facilities, time, social support and motivation, gender and cultural norms, and harsh weather and hot climate were the most commonly reported 
barriers to PA. Specific socio-demographic factors, such as advanced age, less education, being female, and being married, were found to be negatively associated with PA. Gaining health benefits, being male, losing/maintaining weight, dietary habits, recreation, and increased Body Mass Index were identified as PA facilitators. Most data reported on the topic were available from the high-income MENA countries.

PA is developed as a behavior through complex and dynamic interrelations between multiple factors including intrapersonal, interpersonal, and environmental [143,144]. Several of PA facilitators and barriers reported in MENA countries are also reported worldwide. Our study finds variability in the reported facilitators and barriers within the MENA countries. Borrowing from international and regional experience, while some blanket interventions would be required, there is also a need to design country-specific interventions considering local sociocultural and environmental factors influencing PA. Available evidence from low-middle income countries indicates that multicomponent (e.g., media, behavioral, social, policy, and environmental), multisector (e.g., public health, transportation, recreation, health care), and multisite (e.g., work, school, community organization) community-wide campaigns, can be effective in increasing participation in PA [144]. However, there are important barriers to policy implementation, such as insufficiently trained workforce to implement PA policies. These barriers must be overcome before progress in increasing PA can be expected [144]. An important next step would be to build capacity for physical activity surveillance, intervention research, and policy implementation, especially among low-middle income countries [144].

\subsection{Intrapersonal Factors}

The presence of a health condition, such as being overweight or having a pre-existing medical illness, as well as the consumption of foods high in fats/salt/sugar, were identified as barriers to PA. However, in some studies, they were also identified as facilitators to PA, as explained below. Although the presence of a health condition can restrict PA participation, for some individuals, the health condition can act as a 'motivator' to become more physically active in order to improve their health status [28]. Higher PA levels observed in some studies among youth who were consuming foods high in sugar and fast food (rich in fats and salt) can be explained by the fact that, following sporting events and environments, youth may be more likely to consume sugary beverages and unhealthy snacks (through vending machines, commercial presences, etc.) [75]. A reported rise in the consumption of sports drinks and energy drinks (generally high in sugar) $[145,146]$, which are often marketed to youth to assist or enhance exercise or sports performance, can be linked to increased consumption among youth who follow exercise regimens [146].

Individual perception of the impact of PA on health status influences the actual practice of PA. Health benefits related to PA, such as improved balance and walking ability, reduced muscle pain, improved sleep, and muscle strengthening, were found to be major facilitators for the initiation and continuation of PA [28,147-149]. However, failure to perceive the health benefits has been reported as a barrier to PA [148,150].

Particularly in the elderly, inadequate levels of PA were associated with fear of injury or pain $[148,151]$. Health care providers must be cognizant of these fears when counseling the elderly population $[148,149]$. It is important to minimize the risk of injury and the fear associated with it by increasing self-awareness and choosing the correct exercise that is appropriate for the individual's age, fitness level, skill level, and health status [152]. To prevent injury from PA, individuals should be encouraged to practice warm up and cool down activities before and after the PA session. Individuals may want to initiate their PA regimen under the supervision of an exercise instructor to ensure proper technique and to choose the appropriate program for them. Due to safety concerns, fear of walking at night outside the home has been cited as deterrent to PA [148].

Motivation for PA was associated with increased PA participation [7,153]. Motivating factors for PA include pleasure experienced while exercising [153] and scheduling PA for times in the day or the week when energy levels are high. Convincing oneself that PA 
increases energy levels is also a motivator for increased PA participation [152]. Preference to engage in PA as a group or while enjoying the natural scenery may also motivate others $[148,150]$. These motivational aspects can be taken into consideration while planning interventions to promote PA.

Lack of time was reported as a universal barrier to PA for all age groups $[7,28,73,150$, 154]. Reasons reported for the unavailability of time for PA include household responsibilities (e.g., household chores, childcare), extra office work for men, frequent social gatherings, and time management challenges related to heavy school workload $[28,148,155]$. To address this barrier, one can identify at least five 30-min time slots weekly for the purpose of PA. Monitoring daily activity with the aid of a smart phone and fitness trackers, PA apps can also help encourage individuals to indulge in regular PA [156,157]. Walking or riding a bike to work, taking the stairs instead of the elevators, exercising while watching TV, and parking farther away from a destination are effective ways to add PA to a daily routine [158]. Where possible, taking advantage of work PA facilities or programs, walking while on a call, or stretching and moving around can also be useful in facilitating PA [152].

\subsection{Interpersonal Factors}

The absence of social support was reported as a barrier to PA $[7,148]$ in high and low-middle income countries of the MENA region. This is also observed in other regions of the world [144]. It has been shown that adolescents who have inactive parents and minimal support from their friends to encourage PA tend to be physically inactive [159]. Adolescents who are appreciated by friends as being athletically competent show positive feelings towards practicing PA [7]. Having good informal (family friends) and formal (health care provider) support systems increases PA participation [28]. Social support can increase the self-confidence of individuals and motivate them to begin exercise regimens $[28,148,160]$. The possibility of exercising together is likely to motivate friends and family members to engage in PA [28]. Other facilitators for PA include planning social activities involving exercise and developing new friendships with physically active people by joining a gym, an exercise group, or a hiking club [152]. Elderly individuals may need more social support than younger adults to remain physically active [150]. Health professionals can encourage elderly people to participate in group exercises appropriate for their age, skill, and ability.

\subsection{Environmental Factors}

Lack of sports facilities decreases motivation for PA and was identified as one of the major barriers to PA in our study [161,162]. The lack of sports facilities, lack of support from the immediate environment (e.g., school or institution), and societal and family restriction appears to prevent young Saudi females students from participating in PA [49]. With increasing regional urbanization [163], urban design facilitating PA has been suggested as a potential strategy to mitigate the lack of PA facilities in the urban areas of low- and middle-income MENA countries [144]. With the right level of commitment and resource allocation, this strategy is likely to work and yield good results.

The costs of accessing sports facilities was reported as a barrier to PA in high-income countries of the MENA region and internationally [153]. Selecting PA activities that require minimal use of fitness/sports facilities or equipment, such as walking or jogging, and identifying inexpensive, convenient resources available in the community, such as community education programs, parks, and recreation programs, are likely to mitigate the impact of cost as a barrier to PA [28,152]. Construction of playgrounds, sidewalks, parks, cycling routes/paths, or other communal fitness facilities could motivate individuals to engage in regular PA, such as walking and cycling. Governments play an important role in supporting and funding sports facilities. An example of this is the creation of sports cities, such as the Aspire Zone in Qatar, offering several sports facilities ranging from sports venues, a sports hospital and academies, to parks and open-air activities [164]. The integration of such sports-oriented areas into urban cities demonstrates considerable improvement in PA indicators (overall PA, organized sport participation, sedentary be- 
haviors, physical education at school, government allocation of funds and resources) [165]. In addition, the availability of resting space, such as benches for resting in between long walks, is important to ensure easy access to a safe and pleasant place for exercise $[148,166]$.

Extreme weather (very cold or very hot seasons) was linked to a decrease in PA levels in several MENA countries and globally [73,150,153,166,167]. A higher participation in PA was observed during sunny weather and at moderate temperatures $\left(15-27^{\circ} \mathrm{C}\right)[148]$. To facilitate PA in extreme weather, one can choose activities, such as indoor cycling, aerobic dance, indoor swimming, stair climbing, or mall walking, that are always available regardless of the weather [152].

\subsection{Population Groups, Sub-Groups, and Facilitators}

Youth engage in lower levels of PA compared to adults in the MENA region, as well as globally [3]. Some data indicate that midlife adults are less likely to engage in PA and are probably more at risk for unhealthy aging than young adults and the elderly [168]. Midlife adults also perceive fewer health benefits of PA than young and older adults do [168]. Decline in PA is well-documented worldwide once people attain parenthood, particularly for women [169-171]. Parents face numerous barriers to PA including family responsibility, guilt of not spending adequate time with the family, lack of support, scheduling constraints, and work [158]. Understanding barriers in population sub-groups is essential for developing age-appropriate interventions to promote PA. Parents who regularly engage in PA during their daily routine have developed strategies that allow them to balance household and employment responsibilities. These strategies include being active with children or during children's activities, making time/prioritizing, considering benefits to health and family, having support available (family, friends, or child minder), and being a role model for children [158]. Working mothers have been identified as a population that could benefit significantly from interventions that are custom tailored to promote and facilitate PA among them $[169,171]$. Working parents can benefit from interventions that teach them strategies to overcome barriers to PA participation and to enable them to prioritize it parallel to the demands of parenthood [158].

In both adults and youth, males engage in PA more than females $[3,7]$. This gender difference is generally prevalent globally [172-174]. In MENA countries, young females as compared to young males reporting significant barriers related to lack of energy, greater interest in other activities, lack of encouragement, worries about looks, and time constraints from academic responsibilities and family obligations [7,103]. Among youth, boys place more importance on being good in sports, whereas girls focus on good grades and being attractive [175]. Attempts to regulate weight was the main motivator for meeting the recommended levels of PA among youth in Oman and in the U.S. [103,159]. Personal and social barriers to PA are higher among females than males in Arab countries $[7,28,159]$. These include the traditional roles for women and family obligations, lack of social support for women to exercise, and the use of housemaids [28]. In addition, greater freedom and additional facilities to engage in PA and other recreational activities were more available to males as compared to females [7,176]. Proposed interventions to increase PA participation among women included the provision of additional women only sessions or facilities to reduce anxiety related to self-consciousness [177]. Providing enhanced support to girls during the transition from secondary school to college or university or leaving school for employment where levels of sports participation may be affected could also help with their increased uptake of PA [177].

Students in some MENA countries reported limited opportunities (less support from teachers, and lack of time, family/cultural constraints) for exercising $[7,103]$ as a barrier to PA. It is essential to maximize the role of schools in increasing the awareness about, and creating an environment that facilitates, PA. Although young adults in general seem to be aware of benefits related to PA, those from a lower socioeconomic background might have lower levels of awareness [34,49]. Obese university students perceive a higher number of barriers to practicing a healthy lifestyle, including engagement in PA, than non-obese 
students [73]. PA barriers in these students are related to motivation, enjoyment, and skills or ability to exercise [73].

The appeal of television, playing electronic games, and use of computers and mobile devices has increased sedentary time for children [176]. The focus of future studies should be on investigating the barriers to participation in physical education classes and exploring how these barriers can be addressed [7,103]. Inculcating PA habits among schoolchildren and adults can play an important role in the prevention and control of NCDs. Both sociocultural and intrapersonal factors influencing PA participation must be taken into account, as well as the environmental factors.

\subsection{Strengths and Limitations}

To our knowledge, this is the most comprehensive systematic overview on PA barriers and facilitators in the MENA region. The country-specific data on PA barriers will serve as a benchmark for epidemiologists and public health interventionists and can help direct future investigation and research. Limitations include the restriction of the search strategy to PubMed/MEDLINE and Google Scholar. However, the included SRs have searched several literature sources for primary studies, which minimizes the risk of publication bias in our overview. The included studies on factors associated with participation in PA were published up to 2018; new studies from MENA countries may have been published since. Limited data on organizational and policy level factors are available for the region. The absence of data on barriers and/or facilitators of PA in some MENA countries does not mean that PA barriers or facilitators are non-existent in those countries. In addition, other barriers and facilitators, not yet identified in the included studies, could also exist in the MENA countries. We identified barriers predominantly for high-income MENA countries. This could be explained by a higher number of research studies being conducted in these countries rather than the actual existence of increased barriers to PA as compared to lowand middle-income MENA countries.

The majority of the included studies were cross-sectional and had not been designed to assess causal association. SRs reporting these studies have not provided an adequate description of the type of the effect size (e.g., relative risk, odds ratio, correlation), the control for potential confounders, and the strength of the association to determine whether the identified barriers or facilitators are independently associated with the participation in PA. We considered these factors as potential barriers or facilitators based on the study's conclusions. Therefore, further studies are needed for confirmation. The SRs identified variation in PA measurement tools and in the methodology used to conduct the studies, as well as in the methodological quality between the included studies. These limitations within the included studies may prevent deriving high quality evidence. However, the evidence that we have identified and synthesized in this overview is informative and can guide future research. Some identified barriers and facilitators in MENA countries were also identified in other countries worldwide, which support our findings.

\section{Conclusions}

Several of the reported personal and environmental barriers to PA in MENA countries are universal. The lack of suitable sports facilities and extreme weather conditions are more pronounced in some of the MENA countries than others. Advanced age and being a female, less educated, or married are associated with low PA participation. Gaining health benefits, losing/maintaining weight, dietary habits, recreation, and increased Body Mass Index were positively associated with increased levels of PA. Further research is needed to identify additional aspects of gender- and age-specific PA barriers and facilitators. Most retrieved data included on the topic in this paper was obtained from high-income MENA countries, which may have relevance in furthering our research goal of optimum physical activity for the region at large.

Interventions to promote PA in MENA countries should target schoolchildren, working parents, and the elderly. Specific attention should be paid to addressing specific barriers 
to PA among women and girls. Support from parents, friends, and teachers for PA must be encouraged. Programs and activities that address barriers and constraints can be expected to increase awareness of the benefits of, and promote recommended levels of, PA. International experiences could provide the much-needed inspiration. There is a need to design and implement country-, sociocultural-, and environmental-specific PA interventions. In addition, the effectiveness of policies and national interventions currently in place to promote PA in MENA countries must be continually assessed and evaluated to ensure that they are fulfilling the desired outcomes.

Supplementary Materials: The following are available online at https:/ / www.mdpi.com/1660-460 1/18/4/1647/s1, Panel 1: Search strategy.

Author Contributions: S.C. (Sonia Chaabane), K.C., S.D., R.M., and S.C. (Sohaila Cheema) collectively contributed to the conception of the study. S.C. (Sonia Chaabane), K.C., S.D., and S.C. (Sohaila Cheema) were involved in the literature search, screening, and extraction steps. Analysis and manuscript drafting were implemented by S.C. (Sonia Chaabane) with support from K.C., S.D., S.C. (Sohaila Cheema), and R.M. All authors have read and agreed to the published version of the manuscript.

Funding: This research received no specific grant.

Acknowledgments: We would like to thank Amit Abraham, Project Specialist for his assistance with the search strategy and Anupama Jitesh, Research Coordinator for her help with data extraction (barriers to physical activity). Both work at the Institute for Population Health, Weill Cornell MedicineQatar. We would also like to thank Sinéad O'Rourke, Content Development Specialist, Weill Cornell Medicine-Qatar for editing the manuscript.

Conflicts of Interest: The authors report no potential conflict of interest.

\section{References}

1. Bull, F.C.; Al-Ansari, S.S.; Biddle, S.; Borodulin, K.; Buman, M.P.; Cardon, G.; Carty, C.; Chaput, J.-P.; Chastin, S.; Chou, R.; et al. World Health Organization 2020 guidelines on physical activity and sedentary behaviour. Br. J. Sports Med. 2020, 54, 1451-1462. [CrossRef]

2. World Health Organization (WHO). Global Recommendations on Physical Activity for Health. In Global Recommendations on Physical Activity for Health; World Health Organization: Geneva, Switzerland, 2010.

3. Chaabane, S.; Chaabna, K.; Abraham, A.; Mamtani, R.; Cheema, S. Physical activity and sedentary behaviour in the Middle East and North Africa: An overview of systematic reviews and meta-analysis. Sci. Rep. 2020, 10, 9363. [CrossRef]

4. Hurt, R.T.; Kulisek, C.; Buchanan, L.A.; McClave, S.A. The Obesity Epidemic: Challenges, Health Initiatives, and Implications for Gastroenterologists. Gastroenterol. Hepatol. 2010, 6, 780-792.

5. Nikoloski, Z.; Williams, G. Obesity in Middle East. In Metabolic Syndrome; Ahima, R.S., Ed.; Springer International Publishing Switzerland: Philadelphia, PA, USA, 2016.

6. International Diabetes Federation (IDF). IDF Diabetes Atlas; IDF: Brussels, Belgium, 2017.

7. Musaiger, A.O.; Al-Mannai, M.; Tayyem, R.; Al-Lalla, O.; Ali, E.Y.; Kalam, F.; Benhamed, M.M.; Saghir, S.; Halahleh, I.; Djoudi, Z.; et al. Perceived barriers to healthy eating and physical activity among adolescents in seven Arab countries: A cross-cultural study. Sci. World J. 2013, 2013, 232164. [CrossRef]

8. Church, T.S.; Thomas, D.M.; Tudor-Locke, C.; Katzmarzyk, P.T.; Earnest, C.P.; Rodarte, R.Q.; Martin, C.K.; Blair, S.N.; Bouchard, C. Trends over 5 decades in U.S. occupation-related physical activity and their associations with obesity. PLoS ONE 2011, 6, e19657. [CrossRef]

9. White, R.L.; Babic, M.J.; Parker, P.D.; Lubans, D.R.; Astell-Burt, T.; Lonsdale, C. Domain-Specific Physical Activity and Mental Health: A Meta-analysis. Am. J. Prev. Med. 2017, 52, 653-666. [CrossRef]

10. Musaiger, A.O.; Zagzoog, N. Dietary and lifestyle habits among adolescent girls in Saudi Arabia. Nutr. Food Sci. 2013, 43, 605-610. [CrossRef]

11. Musaiger, A.O.; Radwan, H.M. Social and dietary factors associated with obesity in university female students in United Arab Emirates. J. R. Soc. Health 1995, 115, 96-99. [CrossRef] [PubMed]

12. Musaiger, A.O.; Bader, Z.; Al-Roomi, K.; D'Souza, R. Dietary and lifestyle habits amongst adolescents in Bahrain. Food Nutr. Res. 2011, 55. [CrossRef] [PubMed]

13. Musaiger, A.O.; Al-Roomi, K.; Bader, Z. Social, dietary and lifestyle factors associated with obesity among Bahraini adolescents. Appetite 2014, 73, 197-204. [CrossRef]

14. World Health Organization. Global Action Plan for the Prevention and Control of NCDs 2013-2020; WHO: Geneva, Switzerland, 2013. 
15. Mabry, R.; Siyabi, H.; Kannan, M.; Siyabi, A. Move for health: Addressing the built environment and physical activity in Oman. East. Mediterr. Health J. 2019, 25, 923-927. [CrossRef] [PubMed]

16. Aspetar. The State of Qatar National Physical Activity Guidelines, 1st ed.; Aspetar: Doha, Qatar, 2014.

17. Chaabna, K.; Cheema, S.; Abraham, A.; Alrouh, H.; Mamtani, R.; Sheikh, J.I. Gray literature in systematic reviews on population health in the Middle East and North Africa: Protocol of an overview of systematic reviews and evidence mapping. Syst. Rev. 2018, 7, 94. [CrossRef] [PubMed]

18. Chaabna, K.; Cheema, S.; Abraham, A.; Mamtani, R. Strengthening literature search strategies for systematic reviews reporting population health in the Middle East and North Africa: A meta-research study. J. Evid. Based Med. 2020. [CrossRef]

19. Higgins, J.; Green, S. Cochrane Handbook for Systematic Reviews of Interventions Version 5.1.0.; The Cochrane Collaboration: Chichester, $\mathrm{UK}, 2011$.

20. Ouzzani, M.; Hammady, H.; Fedorowicz, Z.; Elmagarmid, A. Rayyan-A web and mobile app for systematic reviews. Syst. Rev. 2016, 5, 210. [CrossRef]

21. The World Bank. World Bank Country and Lending Groups. Available online: https://datahelpdesk.worldbank.org/ knowledgebase/articles / 906519-world-bank-country-and-lending-groups (accessed on 20 January 2021).

22. Shea, B.J.; Grimshaw, J.M.; Wells, G.A.; Boers, M.; Andersson, N.; Hamel, C.; Porter, A.C.; Tugwell, P.; Moher, D.; Bouter, L.M. Development of AMSTAR: A measurement tool to assess the methodological quality of systematic reviews. BMC Med. Res. Methodol. 2007, 7, 10. [CrossRef]

23. Institute of Medicine (US) Committee on Educating Public Health Professionals for the 21st Century. Who Will Keep the Public Healthy? Workshop Summary; Hernandez, L., Ed.; National Academies Press (US): Washington, DC, USA, 2003. Available online: https: / www.ncbi.nlm.nih.gov / books/NBK221695/ (accessed on 21 July 2020).

24. Shea, B.J.; Hamel, C.; Wells, G.A.; Bouter, L.M.; Kristjansson, E.; Grimshaw, J.; Henry, D.A.; Boers, M. AMSTAR is a reliable and valid measurement tool to assess the methodological quality of systematic reviews. J. Clin. Epidemiol. 2009, 62, 1013-1020. [CrossRef]

25. Mabry, R.; Koohsari, M.J.; Bull, F.; Owen, N. A systematic review of physical activity and sedentary behaviour research in the oil-producing countries of the Arabian Peninsula. BMC Public Health 2016, 16, 1003. [CrossRef] [PubMed]

26. Al-Hazzaa, H.M. Physical inactivity in Saudi Arabia revisited: A systematic review of inactivity prevalence and perceived barriers to active living. Int. J. Health Sci. 2018, 12, 50-64.

27. Sharara, E.; Akik, C.; Ghattas, H.; Obermeyer, C.M. Physical inactivity, gender and culture in Arab countries: A systematic assessment of the literature. BMC Public Health 2018, 18, 639. [CrossRef]

28. Benjamin, K.; Donnelly, T.T. Barriers and facilitators influencing the physical activity of Arabic adults: A literature review. Avicenna 2013, 2013. [CrossRef]

29. Al-Nozha, M.M.; Al-Hazzaa, H.M.; Arafah, M.R.; Al-Khadra, A.; Al-Mazrou, Y.Y.; Al-Maatouq, M.A.; Khan, N.B.; Al-Marzouki, K.; Al-Harthi, S.S.; Abdullah, M.; et al. Prevalence of physical activity and inactivity among Saudis aged 30-70 years. A populationbased cross-sectional study. Saudi Med. J. 2007, 28, 559-568.

30. Amin, T.T.; Al Khoudair, A.S.; Al Harbi, M.A.; Al Ali, A.R. Leisure time physical activity in Saudi Arabia: Prevalence, pattern and determining factors. Asian Pac. J. Cancer Prev. 2012, 13, 351-360. [CrossRef]

31. Al-Gelban, K.S. Dietary habits and exercise practices among the students of a Saudi Teachers' Training College. Saudi Med. J. 2008, 29, 754-759.

32. Al-Hazzaa, H.M. Health-enhancing physical activity among Saudi adults using the International Physical Activity Questionnaire (IPAQ). Public Health Nutr. 2007, 10, 59-64. [CrossRef]

33. Al-Hazzaa, H.M. Pedometer-determined physical activity among obese and non-obese 8- to 12-year-old Saudi schoolboys. J. Physiol. Anthr. 2007, 26, 459-465. [CrossRef]

34. Taha, A.Z. Self-reported knowledge and pattern of physical activity among school students in Al Khobar, Saudi Arabia. East Mediterr. Health J. 2008, 14, 344-355.

35. Al-Hazzaa, H.M.; Alahmadi, M.A.; Al-Sobayel, H.I.; Abahussain, N.A.; Qahwaji, D.M.; Musaiger, A.O. Patterns and determinants of physical activity among Saudi adolescents. J. Phys. Act. Health 2014, 11, 1202-1211. [CrossRef] [PubMed]

36. Al-Sobayel, H.; Al-Hazzaa, H.M.; Abahussain, N.A.; Qahwaji, D.M.; Musaiger, A.O. Gender differences in leisure-time versus non-leisure-time physical activity among Saudi adolescents. Ann. Agric. Environ Med. 2015, 22, 344-348. [CrossRef] [PubMed]

37. Collison, K.S.; Zaidi, M.Z.; Subhani, S.N.; Al-Rubeaan, K.; Shoukri, M.; Al-Mohanna, F.A. Sugar-sweetened carbonated beverage consumption correlates with BMI, waist circumference, and poor dietary choices in school children. BMC Public Health 2010, 10, 234. [CrossRef] [PubMed]

38. Ng, S.W.; Zaghloul, S.; Ali, H.; Harrison, G.; Yeatts, K.; El Sadig, M.; Popkin, B.M. Nutrition transition in the United Arab Emirates. Eur. J. Clin. Nutr. 2011, 65, 1328-1337. [CrossRef]

39. Al-Hazzaa, H.M.; Al-Nakeeb, Y.; Duncan, M.J.; Al-Sobayel, H.I.; Abahussain, N.A.; Musaiger, A.O.; Lyons, M.; Collins, P.; Nevill, A. A cross-cultural comparison of health behaviors between Saudi and British adolescents living in urban areas: Gender by country analyses. Int. J. Environ. Res. Public Health 2013, 10, 6701-6720. [CrossRef]

40. Amin, T.T.; Suleman, W.; Ali, A.; Gamal, A.; Al Wehedy, A. Pattern, prevalence, and perceived personal barriers toward physical activity among adult Saudis in Al-Hassa, KSA. J. Phys. Act. Health 2011, 8, 775-784. [CrossRef] [PubMed] 
41. Al-Hazzaa, H.M.; Al-Rasheedi, A.A. Adiposity and physical activity levels among preschool children in Jeddah, Saudi Arabia. Saudi Med. J. 2007, 28, 766-773.

42. Al-Rafaee, S.A.; Al-Hazzaa, H.M. Physical activity profile of adult males in Riyadh City. Saudi Med. J. 2001, 22, 784-789.

43. Garawi, F.; Ploubidis, G.B.; Devries, K.; Al-Hamdan, N.; Uauy, R. Do routinely measured risk factors for obesity explain the sex gap in its prevalence? Observations from Saudi Arabia. BMC Public Health 2015, 15, 254. [CrossRef]

44. Almajwal, A.M. Correlations of Physical Activity, Body Mass Index, Shift Duty, and Selected Eating Habits among Nurses in Riyadh, Saudi Arabia. Ecol. Food Nutr. 2015, 54, 397-417. [CrossRef]

45. Khalaf, A.; Ekblom, O.; Kowalski, J.; Berggren, V.; Westergren, A.; Al-Hazzaa, H. Female university students' physical activity levels and associated factors-a cross-sectional study in southwestern Saudi Arabia. Int. J. Environ. Res. Public Health 2013, 10, 3502-3517. [CrossRef]

46. AlQuaiz, A.M.; Kazi, A.; Tayel, S.; Shaikh, S.A.; Al-Sharif, A.; Othman, S.; Habib, F.; Fouda, M.; Sulaimani, R. Prevalence and factors associated with low bone mineral density in Saudi women: A community based survey. BMC Musculoskelet. Disord. 2014, 15, 5. [CrossRef]

47. Amin, T.T.; Al-Hammam, A.M.; AlMulhim, N.A.; Al-Hayan, M.I.; Al-Mulhim, M.M.; Al-Mosabeh, M.J.; Al-Subaie, M.A.; AlHmmad, Q.A.; Al-Omran, A.A. Physical activity and cancer prevention: Awareness and meeting the recommendations among adult Saudis. Asian Pac. J. Cancer Prev. 2014, 15, 2597-2606. [CrossRef] [PubMed]

48. Gawwad, E.S.A. Stages of change in physical activity, self efficacy and decisional balance among saudi university students. J. Fam. Community Med. 2008, 15, 107-115.

49. Samara, A.; Nistrup, A.; Al-Rammah, T.Y.; Aro, A.R. Lack of facilities rather than sociocultural factors as the primary barrier to physical activity among female Saudi university students. Int. J. Womens Health 2015, 7, 279-286. [CrossRef] [PubMed]

50. Awadalla, N.J.; Aboelyazed, A.E.; Hassanein, M.A.; Khalil, S.N.; Aftab, R.; Gaballa, I.I.; Mahfouz, A.A. Assessment of physical inactivity and perceived barriers to physical activity among health college students, south-western Saudi Arabia. East Mediterr. Health J. 2014, 20, 596-604. [CrossRef]

51. Al-Otaibi, H.H. Measuring stages of change, perceived barriers and self efficacy for physical activity in Saudi Arabia. Asian Pac. J. Cancer Prev. 2013, 14, 1009-1016. [CrossRef]

52. Mandil, A.M.; Alfurayh, N.A.; Aljebreen, M.A.; Aldukhi, S.A. Physical activity and major non-communicable diseases among physicians in Central Saudi Arabia. Saudi Med. J. 2016, 37, 1243-1250. [CrossRef] [PubMed]

53. Alquaiz, A.M.; Kazi, A.; Qureshi, R.; Siddiqui, A.R.; Jamal, A.; Shaik, S.A. Correlates of cardiovascular disease risk scores in women in Riyadh, Kingdom of Saudi Arabia. Women Health 2015, 55, 103-117. [CrossRef]

54. AlQuaiz, A.M.; Tayel, S.A. Barriers to a healthy lifestyle among patients attending primary care clinics at a university hospital in Riyadh. Ann. Saudi Med. 2009, 29, 30-35. [CrossRef] [PubMed]

55. Alsubaie, A.S.R.; Omer, E.O.M. Physical Activity Behavior Predictors, Reasons and Barriers among Male Adolescents in Riyadh, Saudi Arabia: Evidence for Obesogenic Environment. Int. J. Health Sci. 2015, 9, 400-408. [CrossRef]

56. AboZaid, H.A.; Farahat, F.M. Physical activity profile among patients attending family medicine clinics in western Saudi Arabia. Saudi Med. J. 2010, 31, 428-433.

57. Al-Rukban, M.O. Obesity among Saudi male adolescents in Riyadh, Saudi Arabia. Saudi Med. J. 2003, $24,27-33$.

58. Al-Nakeeb, Y.; Lyons, M.; Collins, P.; Al-Nuaim, A.; Al-Hazzaa, H.; Duncan, M.J.; Nevill, A. Obesity, physical activity and sedentary behavior amongst British and Saudi youth: A cross-cultural study. Int. J. Environ. Res. Public Health 2012, 9, 1490-1506. [CrossRef]

59. Khalid, M.E.M. The association between strenuous physical activity and obesity in high and low altitude populations in southern Saudi Arabia. Int. J. Obes. Relat. Metab. Disord. J. Int. Assoc. Study Obes. 1995, 19, 776-780.

60. Al-Hazzaa. Physical activity profile of college male students. King Saud Univ. J. (Educ. Sci.) 1990, 2, $383-396$.

61. Majeed, F. Association of BMI with diet and physical activity of female medical students at the University of Dammam, Kingdom of Saudi Arabia. J. Taibah Univ. Med. Sci. 2015, 10, 188-196. [CrossRef]

62. Albawardi, N.M.; Jradi, H.; Al-Hazzaa, H.M. Levels and correlates of physical activity, inactivity and body mass index among Saudi women working in office jobs in Riyadh city. BMC Womens Health 2016, 16, 33. [CrossRef]

63. Berger, G.; Peerson, A. Giving young Emirati women a voice: Participatory action research on physical activity. Health Place 2009, 15, 117-124. [CrossRef] [PubMed]

64. Bajamal, E.; Robbins, L.B.; Ling, J.; Smith, B.; Pfeiffer, K.A.; Sharma, D. Physical Activity Among Female Adolescents in Jeddah, Saudi Arabia: A Health Promotion Model-Based Path Analysis. Nurs. Res. 2017, 66, 473-482. [CrossRef]

65. Al-Mutairi, R.L.; Bawazir, A.A.; Ahmed, A.E.; Jradi, H. Health beliefs related to diabetes mellitus prevention among adolescents in Saudi Arabia. Sultan Qaboos Univ. Med. J. 2015, 15, e398. [CrossRef]

66. Al-Doghether, M.; Al-Tuwijri, A.; Khan, A. Obstacles to preventive intervention. Do physicians' health habits and mind-set towards preventive care play any role? Saudi Med. J. 2007, 28, 1269-1274. [PubMed]

67. Mahfouz, A.A.; Shatoor, A.S.; Khan, M.Y.; Daffalla, A.A.; Mostafa, O.A.; Hassanein, M.A. Nutrition, physical activity, and gender risks for adolescent obesity in Southwestern Saudi Arabia. Saudi J. Gastroenterol. 2011, 17, 318-322. [CrossRef]

68. Daradkeh, G.; Almohannadi, A.; Chandra, P.; Hajr, M.; Muhannadi, H. Physical Activity Profile of Adolescence in the State of Qatar. Int. J. Nutr. Growth 2015, 1, 1-7. 
69. Alam, A.A. Obesity among female school children in North West Riyadh in relation to affluent lifestyle. Saudi Med. J. 2008, 29, 1139-1144.

70. Al-Hazzaa, H.M.; Abahussain, N.A.; Al-Sobayel, H.I.; Qahwaji, D.M.; Musaiger, A.O. Physical activity, sedentary behaviors and dietary habits among Saudi adolescents relative to age, gender and region. Int. J. Behav. Nutr. Phys. Act. 2011, 8, 140. [CrossRef]

71. Memish, Z.A.; Jaber, S.; Mokdad, A.H.; AlMazroa, M.A.; Murray, C.J.; Al Rabeeah, A.A. Burden of disease, injuries, and risk factors in the Kingdom of Saudi Arabia, 1990-2010. Prev. Chronic Dis. 2014, 11, E169. [CrossRef]

72. Al-Baghli, N.A.; Al-Ghamdi, A.J.; Al-Turki, K.A.; El-Zubaier, A.G.; Al-Ameer, M.M.; Al-Baghli, F.A. Overweight and obesity in the eastern province of Saudi Arabia. Saudi Med. J. 2008, 29, 1319-1325.

73. Musaiger, A.O.; Al-Kandari, F.I.; Al-Mannai, M.; Al-Faraj, A.M.; Bouriki, F.A.; Shehab, F.S.; Al-Dabous, L.A.; Al-Qalaf, W.B Perceived barriers to weight maintenance among university students in Kuwait: The role of gender and obesity. Environ. Health Prev. Med. 2014, 19, 207-214. [CrossRef]

74. Alkahtani, S.; Elkilany, A.; Al-Mohannadi, A.; Alduhishy, A. Relationship Between Self-Reported Dietary Intake and Measured Physical Activity among Male Students in the Preparatory Year in University of Dammam in Saudi Arabia. Curr. Res. Nutr. Food Sci. J. 2015, 3, 130-139. [CrossRef]

75. Duncan, M.J.; Al-Hazzaa, H.M.; Al-Nakeeb, Y.; Al-Sobayel, H.I.; Abahussain, N.A.; Musaiger, A.O.; Lyons, M.; Collins, P.; Nevill, A. Anthropometric and lifestyle characteristics of active and inactive Saudi and British adolescents. Am. J. Hum. Biol. 2014, 26, 635-642. [CrossRef]

76. Mabry, R.M.; Winkler, E.A.; Reeves, M.M.; Eakin, E.G.; Owen, N. Correlates of Omani adults' physical inactivity and sitting time. Public Health Nutr. 2013, 16, 65-72. [CrossRef] [PubMed]

77. Al-Eisa, E.S.; Al-Sobayel, H.I. Physical Activity and Health Beliefs among Saudi Women. J. Nutr. Metab. 2012, $2012,642187$. [CrossRef] [PubMed]

78. Faris, M.; Epuru, S.; Al-Shimmari, S.; Al-Shimmari, E. Alarming High Levels of Energy Drinks Consumption among School Children in Hail, Northern Part of Saudi Arabia. Int. J. Child Health Nutr. 2015, 4, 1-13. [CrossRef]

79. Al-Kandari, Y.Y. Prevalence of obesity in Kuwait and its relation to sociocultural variables. Obes. Rev. Off. J. Int. Assoc. Study Obes. 2006, 7, 147-154. [CrossRef]

80. Al-Isa, A.N.; Campbell, J.; Desapriya, E.; Wijesinghe, N. Social and Health Factors Associated with Physical Activity among Kuwaiti College Students. J. Obes. 2011, 2011, 512363. [CrossRef] [PubMed]

81. Alarouj, M.; Bennakhi, A.; Alnesef, Y.; Sharifi, M.; Elkum, N. Diabetes and associated cardiovascular risk factors in the State of Kuwait: The first national survey. Int. J. Clin. Pract. 2013, 67, 89-96. [CrossRef] [PubMed]

82. Serour, M.; Alqhenaei, H.; Al-Saqabi, S.; Mustafa, A.R.; Ben-Nakhi, A. Cultural factors and patients' adherence to lifestyle measures. Br. J. Gen. Pract. J. R. Coll. Gen. Pract. 2007, 57, 291-295.

83. Rahim, H.F.; Sibai, A.; Khader, Y.; Hwalla, N.; Fadhil, I.; Alsiyabi, H.; Mataria, A.; Mendis, S.; Mokdad, A.H.; Husseini, A. Non-communicable diseases in the Arab world. Lancet 2014, 383, 356-367. [CrossRef]

84. Al-Kandari, F.; Vidal, V.L. Correlation of the health-promoting lifestyle, enrollment level, and academic performance of College of Nursing students in Kuwait. Nurs. Health Sci. 2007, 9, 112-119. [CrossRef]

85. Guthold, R.; Ono, T.; Strong, K.L.; Chatterji, S.; Morabia, A. Worldwide variability in physical inactivity a 51-country survey. Am. J. Prev. Med. 2008, 34, 486-494. [CrossRef]

86. Carter, A.O.; Saadi, H.F.; Reed, R.L.; Dunn, E.V. Assessment of obesity, lifestyle, and reproductive health needs of female citizens of Al Ain, United Arab Emirates. J. Health Popul. Nutr. 2004, 22, 75-83.

87. Sabri, S.; Bener, A.; Eapen, V.; Zeid, M.S.A.; Al-Mazrouei, A.M.; Singh, J. Some risk factors for hypertension in the United Arab Emirates. East Mediterr. Health J. 2004, 10, 610-619. [PubMed]

88. Al-Kaabi, J.; Al-Maskari, F.; Saadi, H.; Afandi, B.; Parkar, H.; Nagelkerke, N. Physical activity and reported barriers to activity among type 2 diabetic patients in the United arab emirates. Rev. Diabet. Stud. RDS 2009, 6, 271-278. [CrossRef]

89. Ali, H.I.; Baynouna, L.M.; Bernsen, R.M. Barriers and facilitators of weight management: Perspectives of Arab women at risk for type 2 diabetes. Health Soc. Care Community 2010, 18, 219-228. [CrossRef]

90. Ali, H.I.; Bernsen, R.M.; Baynouna, L.M. Barriers to weight management among Emirati women: A qualitative investigation of health professionals' perspectives. Int. Q. Community Health Educ. 2008, 29, 143-159. [CrossRef]

91. Hashim, R.; Al-Ali, K. Health of dentists in United Arab Emirates. Int. Dent. J. 2013, 63, 26-29. [CrossRef] [PubMed]

92. Abu-Mourad, T.; Alegakis, A.; Shashaa, S.; Koutis, A.; Lionis, C.; Philalithis, A. Individual determinants of primary healthcare utilisation in Gaza Strip, Palestine. J. Epidemiol. Community Health 2008, 62, 701-707. [CrossRef] [PubMed]

93. Kim, H.J.; Choi-Kwon, S.; Kim, H.; Park, Y.H.; Koh, C.K. Health-promoting lifestyle behaviors and psychological status among Arabs and Koreans in the United Arab Emirates. Res. Nurs. Health 2015, 38, 133-141. [CrossRef]

94. Baglar, R. “Oh God, save us from sugar": An ethnographic exploration of diabetes mellitus in the United Arab Emirates. Med. Anthr. 2013, 32, 109-125. [CrossRef]

95. Al Junaibi, A.; Abdulle, A.; Sabri, S.; Hag-Ali, M.; Nagelkerke, N. The prevalence and potential determinants of obesity among school children and adolescents in Abu Dhabi, United Arab Emirates. Int. J. Obes. 2013, 37, 68-74. [CrossRef]

96. Donnelly, T.T.; Al Suwaidi, J.; Al Bulushi, A.; Al Enazi, N.; Yassin, K.; Rehman, A.M.; Hassan, A.A.; Idris, Z. The influence of cultural and social factors on healthy lifestyle of Arabic women. Avicenna 2011. [CrossRef] 
97. Al-Nakeeb, Y.; Lyons, M.; Dodd, L.J.; Al-Nuaim, A. An investigation into the lifestyle, health habits and risk factors of young adults. Int. J. Environ. Res. Public Health 2015, 12, 4380-4394. [CrossRef] [PubMed]

98. Bener, A.; Al-Mahdi, H.S.; Vachhani, P.J.; Al-Nufal, M.; Ali, A.I. Do excessive internet use, television viewing and poor lifestyle habits affect low vision in school children? J. Child Health Care 2010, 14, 375-385. [CrossRef] [PubMed]

99. Donnelly, T.T.; Al Suwaidi, J.; Al Enazi, N.R.; Idris, Z.; Albulushi, A.M.; Yassin, K.; Rehman, A.M.; Hassan, A.H. Qatari women living with cardiovascular diseases-challenges and opportunities to engage in healthy lifestyles. Health Care Women Int. 2012, 33, 1114-1134. [CrossRef] [PubMed]

100. Sulaiman, N.; Hamdan, A.; Bedri, D.; Young, D. Diabetes knowledge and attitudes towards prevention and health promotion: Qualitative study in Sharjah, United Arab Emirates. Int. J. Food Saf. Nutr. Public Health 2009, 2. [CrossRef]

101. Al-Ghawi, A.; Uauy, R. Study of the knowledge, attitudes and practices of physicians towards obesity management in primary health care in Bahrain. Public Health Nutr. 2009, 12, 1791-1798. [CrossRef]

102. Mabry, R.M.; Al-Busaidi, Z.Q.; Reeves, M.M.; Owen, N.; Eakin, E.G. Addressing physical inactivity in Omani adults: Perceptions of public health managers. Public Health Nutr. 2014, 17, 674-681. [CrossRef]

103. Youssef, R.M.; Al Shafie, K.; Al-Mukhaini, M.; Al-Balushi, H. Physical activity and perceived barriers among high-school students in Muscat, Oman. East Mediterr. Health J. 2013, 19, 759-768. [CrossRef]

104. El Ansari, W.; Khalil, K.; Crone, D.; Stock, C. Physical activity and gender differences: Correlates of compliance with recommended levels of five forms of physical activity among students at nine universities in Libya. Cent Eur. J. Public Health 2014, 22, 98-105. [CrossRef]

105. Aounallah-Skhiri, H.; Ben Romdhane, H.; Maire, B.; Elkhdim, H.; Eymard-Duvernay, S.; Delpeuch, F.; Achour, N. Health and behaviours of Tunisian school youth in an era of rapid epidemiological transition. East Mediterr. Health J. 2009, 15, 1201-1214. [PubMed]

106. Maatoug, J.; Harrabi, I.; Hmad, S.; Belkacem, M.; Al'absi, M.; Lando, H.; Ghannem, H. Clustering of risk factors with smoking habits among adults, Sousse, Tunisia. Prev. Chronic Dis. 2013, 10, E211. [CrossRef]

107. Aounallah-Skhiri, H.; Romdhane, H.B.; Traissac, P.; Eymard-Duvernay, S.; Delpeuch, F.; Achour, N.; Maire, B. Nutritional status of Tunisian adolescents: Associated gender, environmental and socio-economic factors. Public Health Nutr. 2008, 11, $1306-1317$. [CrossRef]

108. Lachheb, M. Religion in practice. The veil in the sporting space in Tunisia. Soc. Compass 2012, 59, 120-135. [CrossRef]

109. Sibai, A.M.; Costanian, C.; Tohme, R.; Assaad, S.; Hwalla, N. Physical activity in adults with and without diabetes: From the 'high-risk' approach to the 'population-based' approach of prevention. BMC Public Health 2013, 13, 1002. [CrossRef] [PubMed]

110. Al-Tannir, M.; Kobrosly, S.; Itani, T.; El-Rajab, M.; Tannir, S. Prevalence of physical activity among Lebanese adults: A crosssectional study. J. Phys. Act. Health 2009, 6, 315-320. [CrossRef]

111. Chamieh, M.C.; Moore, H.J.; Summerbell, C.; Tamim, H.; Sibai, A.M.; Hwalla, N. Diet, physical activity and socio-economic disparities of obesity in Lebanese adults: Findings from a national study. BMC Public Health 2015, 15, 279. [CrossRef]

112. Musharrafieh, U.; Tamim, H.M.; Rahi, A.C.; El-Hajj, M.A.; Al-Sahab, B.; El-Asmar, K.; Tamim, H.M. Determinants of university students physical exercise: A study from Lebanon. Int. J. Public Health 2008, 53, 208-213. [CrossRef]

113. Chacar, H.R.; Salameh, P. Public schools adolescents' obesity and growth curves in Lebanon. J. Med. Liban 2011, 59, 80-88. [PubMed]

114. Shediac-Rizkallah, M.C.; Soweid, R.A.A.; Farhat, T.M.; Yeretzian, J. Adolescent health-related behaviors in postwar Lebanon: Findings among students at the American University of Beirut. Int. Q. Community Health Educ. 2000, 20, 115-131. [CrossRef]

115. Fazah, A.; Jacob, C.; Moussa, E.; El-Hage, R.; Youssef, H.; Delamarche, P. Activity, inactivity and quality of life among Lebanese adolescents. Pediatr. Int. 2010, 52, 573-578. [CrossRef]

116. Jabre, P.; Sikias, P.; Khater-Menassa, B.; Baddoura, R.; Awada, H. Overweight children in Beirut: Prevalence estimates and characteristics. Child Care Health Dev. 2005, 31, 159-165. [CrossRef]

117. Nasreddine, L.; Naja, F.; Akl, C.; Chamieh, M.; Karam, S.; Sibai, A.-M.; Hwalla, N. Dietary, lifestyle and socio-economic correlates of overweight, obesity and central adiposity in Lebanese children and adolescents. Nutrients 2014, 6, 1038-1062. [CrossRef]

118. Nouira, A.; Maatoug, J.; Harrabi, I.; Hmad, S.; Belkacem, M.; Slama, S.; al'Absi, M.; Lando, H.; Ghannem, H. Clustering of risk factors in the smoking habits of schoolchildren in Sousse, Tunisia. Int. J. Adolesc. Med. Health 2014, 26, 267-273. [CrossRef]

119. Najdi, A.; El Achhab, Y.; Nejjari, C.; Norat, T.; Zidouh, A.; El Rhazi, K. Correlates of physical activity in Morocco. Prev. Med. 2011, 52, 355-357. [CrossRef]

120. Batnitzky, A. Obesity and household roles: Gender and social class in Morocco. Sociol. Health Illn. 2008, 30, 445-462. [CrossRef] [PubMed]

121. El Rhazi, K.; Nejjari, C.; Zidouh, A.; Bakkali, R.; Berraho, M.; Gateau, P.B. Prevalence of obesity and associated sociodemographic and lifestyle factors in Morocco. Public Health Nutr. 2011, 14, 160-167. [CrossRef]

122. Rguibi, M.; Belahsen, R. High blood pressure in urban Moroccan Sahraoui women. J. Hypertens. 2007, 25, 1363-1368. [CrossRef]

123. Rguibi, M.; Belahsen, R. Overweight and obesity among urban Sahraoui women of South Morocco. Ethn. Dis. $2004,14,542-547$.

124. Rguibi, M.; Belahsen, R. Fattening practices among Moroccan Saharawi women. East Mediterr. Health J. 2006, 12, 619-624.

125. El-Gilany, A.H.; Badawi, K.; El-Khawaga, G.; Awadalla, N. Physical activity profile of students in Mansoura University, Egypt. East Mediterr. Health J. 2011, 17, 694-702. [CrossRef] 
126. Hallaj, F.A.; El Geneidy, M.M.; Mitwally, H.H.; Ibrahim, H.S. Activity patterns of residents in homes for the elderly in Alexandria, Egypt. East Mediterr. Health J. 2010, 16, 1183-1188. [CrossRef]

127. Salazar-Martinez, E.; Allen, B.; Fernandez-Ortega, C.; Torres-Mejia, G.; Galal, O.; Lazcano-Ponce, E. Overweight and obesity status among adolescents from Mexico and Egypt. Arch. Med. Res. 2006, 37, 535-542. [CrossRef]

128. Abolfotouh, M.A.; Bassiouni, F.A.; Mounir, G.M.; Fayyad, R. Health-related lifestyles and risk behaviours among students living in Alexandria University Hostels. East Mediterr. Health J. 2007, 13, 376-391.

129. Fouad, M.; Rastam, S.; Ward, K.; Maziak, W. Prevalence of obesity and its associated factors in Aleppo, Syria. Prev. Control 2006, 2, 85-94. [CrossRef] [PubMed]

130. Al Ali, R.; Rastam, S.; Fouad, F.M.; Mzayek, F.; Maziak, W. Modifiable cardiovascular risk factors among adults in Aleppo, Syria. Int. J. Public Health 2011, 56, 653-662. [CrossRef]

131. Al Sabbah, H.; Vereecken, C.; Kolsteren, P.; Abdeen, Z.; Maes, L. Food habits and physical activity patterns among Palestinian adolescents: Findings from the national study of Palestinian schoolchildren (HBSC-WBG2004). Public Health Nutr. 2007, 10, 739-746. [CrossRef]

132. Abdul-Rahim, H.F.; Holmboe-Ottesen, G.; Stene, L.C.; Husseini, A.; Giacaman, R.; Jervell, J.; Bjertness, E. Obesity in a rural and an urban Palestinian West Bank population. Int. J. Obes. Relat. Metab. Disord. J. Int. Assoc. Study Obes. 2003, 27, 140-146. [CrossRef] [PubMed]

133. Al-Tawil, N.G.; Abdulla, M.M.; Ameer, A.J.A. Prevalence of and factors associated with overweight and obesity among a group of Iraqi women. East Mediterr. Health J. 2007, 13, 420-429.

134. Sirdah, M.M.; Al Laham, N.A.; Ghali, A.S.A. Prevalence of metabolic syndrome and associated socioeconomic and demographic factors among Palestinian adults (20-65 years) at the Gaza Strip. Diabetes Metab. Syndr. 2011, 5, 93-97. [CrossRef]

135. Centers for Disease Control and Prevention. Prevalence of selected risk factors for chronic disease-Jordan, 2002. MMWR Morb. Mortal. Wkly. Rep. 2003, 52, 1042.

136. Nsour, M.; Mahfoud, Z.; Kanaan, M.N.; Balbeissi, A. Prevalence and predictors of nonfatal myocardial infarction in Jordan. East Mediterr. Health J. 2008, 14, 818-830.

137. Madanat, H.; Merrill, R.M. Motivational factors and stages of change for physical activity among college students in Amman, Jordan. Promot. Educ. 2006, 13, 185-190. [CrossRef] [PubMed]

138. Gharaibeh, M.; Al-Ma'aitah, R.; Al Jada, N. Lifestyle practices of Jordanian pregnant women. Int. Nurs. Rev. 2005, 52, 92-100. [CrossRef]

139. Haddad, L.G.; Owies, A.; Mansour, A. Wellness appraisal among adolescents in Jordan: A model from a developing country: A cross-sectional questionnaire survey. Health Promot. Int. 2009, 24, 130-139. [CrossRef]

140. Moukhyer, M.; Van Eijk, J.; De Vries, N.; Bosma, H. Health-related behaviors of Sudanese adolescents. Educ. Health 2008, 21, 184.

141. Dumith, S.C.; Hallal, P.C.; Reis, R.S.; Kohl, H.W., 3rd. Worldwide prevalence of physical inactivity and its association with human development index in 76 countries. Prev. Med. 2011, 53, 24-28. [CrossRef] [PubMed]

142. Guthold, R.; Cowan, M.J.; Autenrieth, C.S.; Kann, L.; Riley, L.M. Physical activity and sedentary behavior among schoolchildren: A 34-country comparison. J. Pediatr. 2010, 157, 43-49.e41. [CrossRef]

143. Golden, S.D.; Earp, J.A.L. Social Ecological Approaches to Individuals and Their Contexts: Twenty Years of Health Education \& Behavior Health Promotion Interventions. Health Educ. Behav. 2012, 39, 364-372. [CrossRef]

144. Sallis, J.F.; Bull, F.; Guthold, R.; Heath, G.W.; Inoue, S.; Kelly, P.; Oyeyemi, A.L.; Perez, L.G.; Richards, J.; Hallal, P.C. Progress in physical activity over the Olympic quadrennium. Lancet 2016, 388, 1325-1336. [CrossRef]

145. The American Academy of Pediatrics. Sports drinks and energy drinks for children and adolescents: Are they appropriate? Pediatrics 2011, 127, 1182-1189. [CrossRef]

146. Zucconi, S.; Volpato, C.; Adinolfi, F.; Gandini, E.; Gentile, E.; Loi, A.; Fioriti, L. Gathering consumption data on specific consumer groups of energy drinks. EFSA Supporting Publ. 2013, 10, 394E. [CrossRef]

147. Costello, E.; Kafchinski, M.; Vrazel, J.; Sullivan, P. Motivators, barriers, and beliefs regarding physical activity in an older adult population. J. Geriatr. Phys. Ther. 2011, 34, 138-147. [CrossRef]

148. Yarmohammadi, S.; Saadati, H.M.; Ghaffari, M.; Ramezankhani, A. A systematic review of barriers and motivators to physical activity in elderly adults in Iran and worldwide. Epidemiol. Health 2019, 41, e2019049. [CrossRef]

149. Vseteckova, J.; Deepak-Gopinath, M.; Borgstrom, E.; Holland, C.; Draper, J.; Pappas, Y.; McKeown, E.; Dadova, K.; Gray, S. Barriers and facilitators to adherence to group exercise in institutionalized older people living with dementia: A systematic review. Eur. Rev. Aging Phys. Act. 2018, 15, 11. [CrossRef]

150. Baert, V.; Gorus, E.; Mets, T.; Geerts, C.; Bautmans, I. Motivators and barriers for physical activity in the oldest old: A systematic review. Ageing Res. Rev. 2011, 10, 464-474. [CrossRef]

151. Lim, K.; Taylor, L. Factors associated with physical activity among older people-A population-based study. Prev. Med. 2005, 40, 33-40. [CrossRef]

152. National Center for Chronic Disease Prevention and Health Promotion. Division of Nutrition, Physical Activity, and Obesity. Overcoming Barriers to Physical Activity. Available online: https://www.cdc.gov/physicalactivity/basics/adding-pa/barriers. html (accessed on 14 June 2020).

153. Salmon, J.; Owen, N.; Crawford, D.; Bauman, A.; Sallis, J.F. Physical activity and sedentary behavior: A population-based study of barriers, enjoyment, and preference. Health Psychol. 2003, 22. [CrossRef] 
154. Lees, F.D.; Clarkr, P.G.; Nigg, C.R.; Newman, P. Barriers to exercise behavior among older adults: A focus-group study. J. Aging Phys. Act. 2005, 13, 23-33. [CrossRef]

155. Hughes, M.E.; Waite, L.J.; LaPierre, T.A.; Luo, Y. All in the Family: The Impact of Caring for Grandchildren on Grandparents' Health. J. Gerontol. Ser. B 2007, 62, S108-S119. [CrossRef]

156. Cadmus-Bertram, L. Using Fitness Trackers in Clinical Research: What Nurse Practitioners Need to Know. J. Nurse Pract. JNP 2017, 13, 34-40. [CrossRef]

157. Ridgers, N.D.; McNarry, M.A.; Mackintosh, K.A. Feasibility and Effectiveness of Using Wearable Activity Trackers in Youth: A Systematic Review. JMIR Mhealth Uhealth 2016, 4, e129. [CrossRef]

158. Mailey, E.L.; Huberty, J.; Dinkel, D.; McAuley, E. Physical activity barriers and facilitators among working mothers and fathers. BMC Public Health 2014, 14, 657. [CrossRef]

159. Patnode, C.D.; Lytle, L.A.; Erickson, D.J.; Sirard, J.R.; Barr-Anderson, D.; Story, M. The relative influence of demographic, individual, social, and environmental factors on physical activity among boys and girls. Int. J. Behav. Nutr. Phys. Act. $2010,7,79$. [CrossRef]

160. de Groot, G.C.; Fagerström, L. Older adults' motivating factors and barriers to exercise to prevent falls. Scand. J. Occup. Ther. 2011, 18, 153-160. [CrossRef]

161. Nadri, A.; Safania, A.M.; Amritash, A.M. Determinant of the implementation of physical activities in elderly in Tehran. J. Gerontol. 2016, 1, 66-79. [CrossRef]

162. Chen, Y.M. Perceived barriers to physical activity among older adults residing in long-term care institutions. J. Clin. Nurs. 2010, 19, 432-439. [CrossRef]

163. United Nations Department of Economic and Social Affairs Population Division. World Urbanization Prospects: The 2014 Revision, Highlights (ST/ESA/SER.A/352); The United Nations: New York, NY, USA, 2014.

164. Azzali, S. The aspire zone in Doha: A post-occupancy evaluation of the long-term legacies of the 2006 Asian games. J. Urban Regen. Renew. 2016, 9, 393-405.

165. Ibrahim, I.; Hammadi, E.; Sayegh, S.; Zimmo, L.; Neama, J.; Rezeq, H.; Al-Mohannadi, A.; Al-Thani, A. Results from Qatar's 2018 Report Card on Physical Activity for Children and Youth. J. Phys. Act. Health 2018, 15, S400-S401. [CrossRef]

166. Price, A.E.; Reed, J.A.; Long, S.; Maslow, A.L.; Hooker, S.P. The association of natural elements with physical activity intensity during trail use by older adults. J. Phys. Act. Health 2012, 9, 718-723. [CrossRef]

167. Schmidt, L.; Rempel, G.; Murray, T.C.; McHugh, T.L.; Vallance, J.K. Exploring beliefs around physical activity among older adults in rural Canada. Int. J. Qual. Stud. Health Well-Being 2016, 11, 32914. [CrossRef] [PubMed]

168. Shin, C.-N.; Lee, Y.-S.; Belyea, M. Physical activity, benefits, and barriers across the aging continuum. Appl. Nurs. Res. 2018, 44, 107-112. [CrossRef]

169. Albright, C.L.; Maddock, J.E.; Nigg, C.R. Physical Activity Before Pregnancy and Following Childbirth in a Multiethnic Sample of Healthy Women in Hawaii. Women Health 2006, 42, 95-110. [CrossRef]

170. Hull, E.E.; Rofey, D.L.; Robertson, R.J.; Nagle, E.F.; Otto, A.D.; Aaron, D.J. Influence of marriage and parenthood on physical activity: A 2-year prospective analysis. J. Phys. Act. Health 2010, 7, 577-583. [CrossRef]

171. McIntyre, C.; Rhodes, R. Correlates of Leisure-Time Physical Activity During Transitions to Motherhood. Women Health 2009, 49, 66-83. [CrossRef]

172. Hallal, P.C.; Andersen, L.B.; Bull, F.C.; Guthold, R.; Haskell, W.; Ekelund, U. Global physical activity levels: Surveillance progress, pitfalls, and prospects. Lancet 2012, 380, 247-257. [CrossRef]

173. Khuwaja, A.K.; Kadir, M.M. Gender differences and clustering pattern of behavioural risk factors for chronic non-communicable diseases: Community-based study from a developing country. Chronic Illn. 2010, 6, 163-170. [CrossRef]

174. Sisson, S.B.; Katzmarzyk, P.T. International prevalence of physical activity in youth and adults. Obes. Rev. Off. J. Int. Assoc. Study Obes. 2008, 9, 606-614. [CrossRef] [PubMed]

175. Chase, M.A.; Dummer, G.M. The role of sports as a social status determinant for children. Res. Q. Exerc. Sport 1992, 63, $418-424$. [CrossRef] [PubMed]

176. Musaiger, A.O. Diet and prevention of coronary heart disease in the Arab Middle East countries. Med. Princ. Pract. Int. J. Kuwait Univ. Health Sci. Cent 2002, 11, 9-16. [CrossRef] [PubMed]

177. Coleman, L.; Cox, L.; Roker, D. Girls and young women's participation in physical activity: Psychological and social influences. Health Educ. Res. 2007, 23, 633-647. [CrossRef] [PubMed] 